\title{
L-Malate Oxidation by the Electron Transport Fraction of Azotobacter vinelandii
}

\author{
PETER JURTSHUK, A. J. BEDNARZ, PININA ZEY, AND C. H. DENTON \\ Department of Microbiology, University of Texas at Austin, Austin, Texas 78712
}

Received for publication 28 February 1969

\begin{abstract}
The membrane-bound L-malate oxidoreductase of Azotobacter vinelandii strain $\mathrm{O}$ was found to be a flavoprotein-dependent enzyme associated with the electron transport system $\left(\mathbf{R}_{3}\right)$ of this organism. The particulate $\mathbf{R}_{3}$ fraction, which possessed the L-malate oxidoreductase, carried out the cyanide-sensitive oxidation of L-malate, D-lactate, reduced nicotinamide adenine dinucleotide and nicotinamide adenine dinucleotide phosphate, succinate, cytochrome $c$, tetramethyl-p-phenylenediamine, and p-phenylenediamine, with molecular $\mathrm{O}_{2}$ as the terminal electron acceptor. D-Malate was not oxidized, but L-malate was oxidized to oxalacetate. Phenazine methosulfate (PMS), vitamin $\mathrm{K}_{3}, \mathrm{~K}_{3} \mathrm{Fe}(\mathrm{CN})_{6}$, nitro blue tetrazolium, and dichloroindophenol all served as good terminal electron acceptors for the L-malate oxidoreductase. Cytochrome $c$ was a poor electron acceptor. Extensive studies on the L-malate oxidase and PMS and $\mathrm{K}_{3}$ reductases revealed that all were stimulated specifically by flavine adenine dinucleotide and nonspecifically by di- or trivalent cations, i.e., $\mathrm{Ca}^{++}, \mathrm{Ba}^{++}, \mathrm{Mn}^{++}, \mathrm{Mg}^{++}, \mathrm{Fe}^{+++}, \mathrm{Ni}^{++}$, and $\mathrm{Al}^{+++}$. All these activities were markedly sensitive to ethylenediaminetetraacetate (EDTA). The $V_{\max }$ values for the L-malate oxidase, PMS, and vitamin $\mathrm{K}_{3}$ reductases were, respectively, $3.4,15.1$, and $45.5 \mu$ moles of substrate oxidized per min per $\mathrm{mg}$ of protein at $37 \mathrm{C}$. Spectral studies revealed that the Azotobacter $\mathbf{R}_{3}$ flavoprotein and cytochromes $\left(a_{2}, a_{1}, b_{1}, c_{4}\right.$, and $\left.c_{5}\right)$ were reduced by L-malate. L-Malate oxidase activity was sensitive to various inhibitors of the electron transport system, namely, $p$-chloromercuriphenylsulfonic acid, chlorpromazine, 2- $n$-heptyl-4-hydroxyquinoline- $N$ oxide, antimycin A, and $\mathrm{KCN}$. Minor inhibitory effects were noted with the inhibitors 4,4,4-trifluoro-1-(2-thienyl)-1, 3-butanedione, rotenone, and Amytal.
\end{abstract}

In mammalian and most microbial systems, $\mathrm{L}-$ malate is oxidized to oxalacetate or pyruvate and $\mathrm{CO}_{2}$ by the soluble nicotinamide adenine dinucleotide (NAD)-dependent malate dehydrogenase (EC 1.1.1.37), malate dehydrogenase (decarboxylating) (EC. 1.1.1.38 and 1.1.1.39), or by the soluble nicotinamide adenine dinucleotide phosphate (NADP)-dependent malate dehydrogenase (decarboxylating) (EC 1.1.1.40). In bacteria, however, there is another enzyme, the L-malate oxidase or oxido reductase (EC 1.1.3.3), a flavoprotein-dependent enzyme which catalyzes the oxidation of Lmalate to oxalacetate. This enzyme has been studied in Mycobacterium phlei $(3-5,11,33,34$, 49), M. avium (32, 47, 48, 50), Acetobacter xylinum (6-10, 31), Micrococcus lysodiekticus (13, 14, 18-22, 36, 39), Pseudomonas ovalis (16,17, 41), Azotobacter agilis $(15,40,43)$, and A. vinelandii $(1,2,12,25,26,46$; P. Jurtshuk, C. H. Denton, and A. J. Bednarz, Bacteriol. Proc., p. 104, 1967). Preliminary indications are that this oxidoreductase may be either soluble or particulate and is closely associated with or part of the electron transport system of microorganisms.

Further studies on the L-malate oxidoreductase in microbial systems revealed that oxidative phosphorylation can occur during this oxidation without the involvement of a pyridine nucleotide $(9,11)$. Cytochromes $(7,8,11,16,18$, $26)$, ubiquinone or coenzyme $Q(8,17,25,41)$, naphthoquinone or vitamin $\mathrm{K}(4,17,48,49)$, nonheme iron $(7,31,33,34)$, and flavoproteins are involved in the overall reaction $(7,11,16,17$, 22, 31, 41, 47). Furthermore, L-malate oxidation in microbial particulate fractions may be associated with or be part of the electron transport chain that carries out reduced nicotinamide adenine dinucleotide (NADH) oxidation $(3,20$, 36). In some of these microbial systems, the flavoprotein moiety of the L-malate oxidoreductase is easily dissociable; restoration of activity is accomplished specifically by the addition of flavine adenine dinucleotide (FAD; 7, 32). Phospholipid 
was also reported to be a component of this system. Numerous reports in the literature suggested that this enzyme may be reactivated by phospholipids $(5,41,47)$.

Malate oxidation has long been known in Azotobacter species (1, 2, 12, 15, 25, 26, 40, 43, 46; P. Jurtshuk, C. H. Denton, and A. J. Bednarz, Bacteriol. Proc., p. 104, 1967). The soluble NADand NADP-dependent (decarboxylating) Lmalate dehydrogenases and the flavoproteincontaining L-malate oxidoreductase are present in high concentrations. The purpose of this investigation was to study the flavoprotein-dependent L-malate oxidoreductase of $A$. vinelandii strain $\mathrm{O}$ with respect to the kinetic properties of this enzyme, its ability to utilize various electron acceptors, its response to cofactors, its sensitivity to inhibitors and chelators, and its relationship to the Azotobacter electron transport system.

\section{MATERIALS AND METHODS}

Chemicals. Abbreviations used in the text are as follows: $p$-CMB, $p$-chloromercuriphenyl sulfonic acid; DCIP, 2,6-dichloroindophenol; EDTA, ethylenediaminetetraacetic acid (disodium salt); FAD; FMN, flavine mononucleotide; HQNO, 2-n-heptyl-4hydroxyquinoline- $N$-oxide; MB, methylene blue; MTT, 3-(4,5-dimethyl thiazolyl-2)-2, 5-diphenyl tetrazolium bromide; NBT, nitro blue tetrazolium; PMS, phenazine methosulfate; PPD, $p$-phenylenediamine; TFTB, 4, 4,4-trifluoro-1-(2-thienyl)-1, 3-butanedione; TMPD, $N, N, N^{\prime}, N^{\prime}$-tetramethyl-p-phenylenediamine dihydrochloride; and $K_{3}$ or vitamin $K_{3}$, menadione, or 2-methyl-1,4-naphthoquinone. The sources of the chemicals were as follows: EDTA, FAD, FMN, Trizma base, $p$-CMB, and $o$-phenanthroline from Sigma Chemical Co., St. Louis, Mo.; riboflavine and 8-hydroxyquinoline from Eastman Organic Chemicals Co., Rochester, N.Y.; L-malate from Calbiochem, Los Angeles, Calif.; NAD and NADP from P-L Biochemicals, Inc., Milwaukee, Wis.; $\alpha, \alpha$-dipyridyl from Matheson Co., Inc., Joliet, Ill. Sources for all other chemicals are listed elsewhere (28).

Chemical methods. FAD, FMN, and riboflavine were prepared in deionized water and standardized spectrophotometrically at $450 \mathrm{~nm}$ by the use of the extinction coefficient of 10.3 per $\mathrm{cm}$ per mM (37). The chelators, 8-hydroxyquinoline and $o$-phenanthroline, as well as the electron transport inhibitors (Amytal, antimycin A, TFTB, HQNO, and rotenone), $p$-CMB, and vitamin $K_{3}$ were prepared in $95 \%$ ethyl alcohol.

The dinitrophenylhydrazine (DNP) derivative of the end product formed from L-malate oxidation was prepared in the conventional manner (45) and chromatographically characterized in the solvent systems previously described (44). Protein was determined by a modification of the biuret method of Gornall, Bardawill, and David (23).

Spectral characterization. The difference spectra (reduced minus oxidized) of the Azotobacter $\mathbf{R}_{3}$ fraction were measured in a Cary model 14 recording spectrophotometer. Details and conditions for these steady-state reductions are presented in Fig. 1.

Preparation of $\mathrm{A}$. vinelandii cell-free extracts. The preparation of the Azotobacter $\mathbf{R}_{\mathbf{3}}$ fraction has been described previously $(29,30)$. This fraction is similar to the electron transport particles isolated and described by other workers $(2,12,15,25,43,46)$. The $\mathbf{R}_{3}$ fraction appeared as a reddish-brown, translucent pellet that was obtained from sonically disrupted resting cells by differential centrifugation. This fraction did not sediment after $20 \mathrm{~min}$ at $37,000 \times \mathrm{g}$ but was sedimented by centrifugation at $144,000 \times g$ for 2 $\mathrm{hr}$. Of all the fractions examined, the $\mathbf{R}_{\mathbf{3}}$ exhibited the highest specific activities for NADH and succinate (27), D-lactate (28), L-malate (P. Jurtshuk, C. H. Denton, and A. J. Bednarz, Bacteriol. Proc., p. 104, 1967), cytochrome $c$ (30), and TMPD and PPD oxidases (27). A fractionation scheme showing the distribution of activity units for L-malate oxidation in cell-free extracts was drawn up (Table 4).

Enzyme assays. L-Malate oxidase activity was measured manometrically in 15-ml Warburg flasks with air as the gas phase. The main compartment contained $33.3 \mathrm{~mm}$ tris(hydroxymethyl)aminomethane (Tris)-hydrochloride $(p \mathrm{H} \mathrm{8.0}), 0.04 \mathrm{mM} \mathrm{FAD}$, and $2.0 \mathrm{~mm}$ metal ion (usually $\mathrm{Ca}^{++}$) when desired, 0.18 or $0.35 \mathrm{mg}$ of protein of the Azotolacter $\mathrm{R}_{3}$ fraction

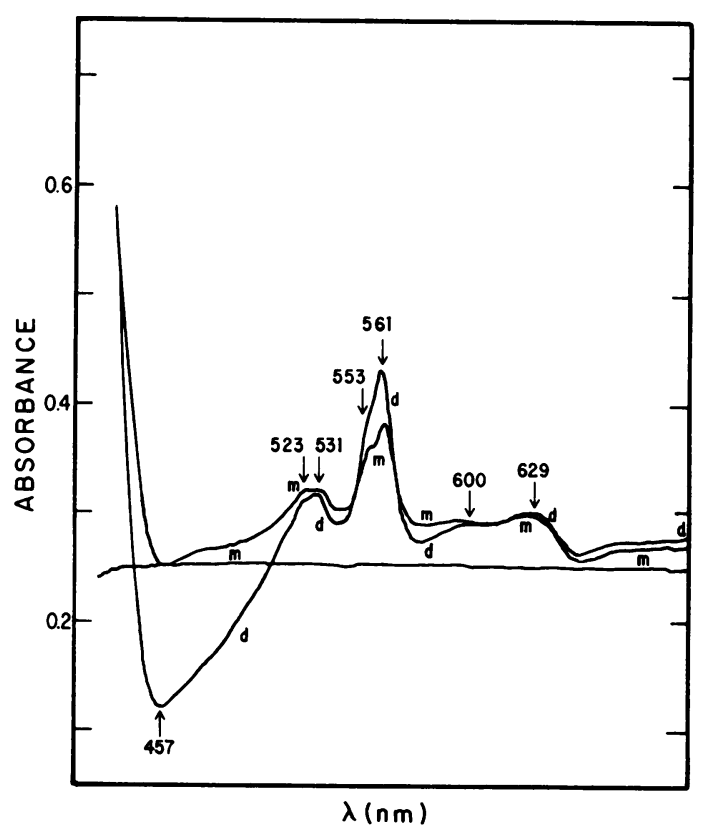

FIG. 1. Difference spectrum (reduced minus oxidized) exhibiting steady-state reduction in the Azotobacter $R_{3}$ electron transport fraction. The spectrum designated by " $m$ " represents the reduction achieved by $0.09 \mathrm{M}$ L-malate and the spectrum represented by " $d$ " shows the chemical reduction achieved by the addition of a few crystals of sodium dithionite. The concentration of the Azotobacter $R_{3}$ fraction was $8.0 \mathrm{mg}$ of protein in $1 \mathrm{ml}$ of $0.02 \mathrm{M}$ phosphate buffer ( $\mathrm{pH} 7.5)$. 
depending upon the presence or absence of cofactors, and deionized water to $3.0 \mathrm{ml}$. The side arm contained $50 \mu$ moles of L-malate and the center well contained $0.2 \mathrm{ml}$ of $2.0 \mathrm{M} \mathrm{KOH}$. The reaction mixtures for the L-malate PMS and L-malate $\mathrm{K}_{3}$ reductase assays were exactly as above, except that $2.0 \mathrm{~mm} \mathrm{KCN}$ was added to the main compartment and either $2 \mathrm{ml}$ of $1 \%$ (w/v) PMS was added to a side arm separate from the substrate or $0.03 \mathrm{ml}$ of $2 \%(\mathrm{w} / \mathrm{v}) \mathrm{K}_{3}$ (in $95 \%$ ethyl alcohol) was added to the main compartment. The amount of Azobacter $\mathbf{R}_{3}$ fraction added ranged from 0.04 to $0.15 \mathrm{mg}$ of protein per $3 \mathrm{ml}$ in the PMS reductase assay and from 0.02 to $0.07 \mathrm{mg}$ of protein per $3 \mathrm{ml}$ in the $K_{3}$ reductase assay. All reactions were initiated by the addition of substrate from the side arm after an initial equilibration period of $7 \mathrm{~min}$. PMS was tipped into the main compartment at the same time as was the substrate in the L-malate PMS reductase assay. All specific activities are expressed as microatoms of oxygen per minute per milligram of protein at 30 or at $37 \mathrm{C}$. All inhibitor titration studies were carried out at $30 \mathrm{C}$, and the Azobacter $\mathbf{R}_{\mathbf{3}}$ fraction was incubated with the inhibitor and both cofactors in the main compartment during the equilibration period prior to the addition of the substrate.

Spectrophotometric assays were carried out at $25 \mathrm{C}$ in quartz cuvettes. The final reaction volume was $1 \mathrm{ml}$. All reactions were initiated by the addition of enzyme, and all rates were corrected for any nonenzymatic rate. Routinely, the assays were performed in $\mathbf{5 0}$ mM Tris buffer ( $p H$ 8.0) with final concentrations of 60 to $70 \mu \mathrm{M}$ FAD, $1.0 \mathrm{mM} \mathrm{MgCl}_{2}, 1.0 \mathrm{mM} \mathrm{KCN}$, and $10.0 \mathrm{mM}$ L-malate. The reaction mixture for the PMSmediated L-malate cytochrome $c$ and DCIP reductase assays contained, in addition to the above, 0.165 mM PMS, and either $0.7 \mathrm{mg}$ of cytochrome $c$ per $\mathrm{ml}$ or $0.04 \mathrm{~mm}$ DCIP. The L-malate cytochrome $c$ and L-malate DCIP reductase assays were carried out as described above, but with the elimination of PMS from the assay cuvette. The reduction of DCIP was monitored at $600 \mathrm{~nm}$ and, for all calculations, the extinction coefficient used was 20.5 per $\mathrm{cm}$ per $\mathrm{mm}$ (51). The reduction of cytochrome $c$ was measured at $550 \mathrm{~nm}$ and the extinction coefficient used was 18.5 per $\mathrm{cm}$ per $\mathrm{mm}$ (38). The L-malate NBT reductase activity was measured by monitoring the increase in absorption at $530 \mathrm{~nm}$ with $84 \mu \mathrm{M} \mathrm{NBT}$, and calculations were based on the extinction coefficient of $\mathbf{1 8 . 0}$ per $\mathrm{cm}$ per $\mathrm{mm}(35)$. The concentration of L-malate used for the NBT reductase assay was $75 \mathrm{~mm}$. The reaction mixture for the L-malate $\mathrm{K}_{3} \mathrm{Fe}(\mathrm{CN})_{6}$ reductase assay contained $40 \mathrm{mM}$ Tris buffer $(p H \mathbf{8} .0)$, $5.0 \mathrm{mM}$ L-malate, $1.0 \mathrm{MgCl}_{2}, 1.6 \mathrm{mM} \mathrm{K}_{3} \mathrm{Fe}(\mathrm{CN})_{6}$, and $60 \mu \mathrm{M}$ FAD. The reaction was monitored at 420 $\mathrm{nm}$ and the specific activity was calculated by the use of an extinction coefficient for ferricyanide of 1.0 per cm per mM $(24,51)$.

\section{RESULTS}

Stoichiometry of the reaction. L-Malate was oxidized by the L-malate oxidase in the Azotobacter $\mathbf{R}_{3}$ fraction according to the following reaction:

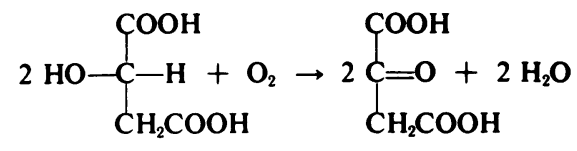

The enzymatic oxidation was found to be stoichiometric since $30 \mu$ moles of L-malate was oxidized completely with the resultant uptake of $15 \mu$ moles of $\mathrm{O}_{2}$. The keto end product formed could be trapped as the DNP derivative (45). Paper chromatographic analyses of $\boldsymbol{R}_{\boldsymbol{F}}$ values, with three solvent systems (44), revealed that the keto-DNP derivative formed from L-malate oxidation was identical to a known authentic sample of 2,4dinitrophenylhydrazone of oxalacetate.

Specificity of the enzyme for L-malate. The malate oxidoreductase activity in the Azotobacter $\mathbf{R}_{\mathbf{3}}$ fraction was specific for $\mathbf{L}$-malate. The unnatural isomer, $D$-malate, was not oxidized by this enzyme fraction (28).

Effect of metal ions and FAD in L-malate oxidation. The oxidation of L-malate by the Azotobacter $\mathbf{R}_{\mathbf{3}}$ fraction was assayed readily by using molecular $\mathrm{O}_{2}, \mathrm{PMS}$, and $\mathrm{K}_{3}$ as electron acceptors. L-Malate oxidation was stimulated by the addition of FAD or metal ion, or both, and this stimulation occurred regardless of the electron acceptor used (Table 1). The enzymatic activity was found to be maximum only when both FAD and metal ion were present in the reaction vessel. The stimulation by metal ions was nonspecific and a large number of cations could substitute for $\mathrm{Ca}^{++}$ion. Only $\mathrm{Ba}^{++}$, however, was as effective as $\mathrm{Ca}^{++}$in stimulating $\mathrm{L}$-malate oxidation. As would be expected from the above findings, L-malate oxidation by the Azotobacter $\mathbf{R}_{\mathbf{3}}$ fraction was sensitive to chelating agents, namely, EDTA, o-phenanthroline, 8-hydroxyquinoline, and to a lesser extent to $\alpha, \alpha$-dipyridyl.

In contrast to the stimulation observed with metal ions, it was found that stimulation by FAD

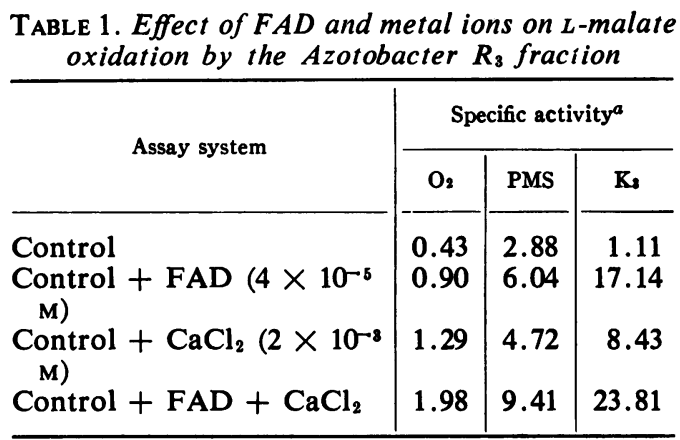

a Expressed in microatoms of oxygen per minute per milligram of protein at $30 \mathrm{C}$. 
was highly specific (Table 2). Neither FMN nor riboflavine could substitute for FAD in stimulating L-malate oxidation, and neither NAD nor NADP influenced this oxidation. Stimulation of the L-malate oxidase activity by FAD, either in the presence or absence of metal ion, was sensitive to cyanide, suggesting that terminal oxidation via the electron transport system was still involved for the stimulated rates.

Development of assay and enzyme kinetics. Experiments were performed which were designed to define the kinetic characteristics of the Azotobacter $\mathbf{R}_{3}$ L-malate oxidoreductase. Each artificial electron acceptor (PMS and vitamin $\mathrm{K}_{3}$ ), as well as the substrate L-malate, was titrated by the use of the manometric assays. The $V_{\max }$ and $K_{\mathrm{m}}$ values were calculated (Table 3 ).

The $V_{\max }$ values calculated, with L-malate as the variable for the malate oxidase and the malate$\mathrm{K}_{3}$ and malate-PMS reductase assays, were slightly higher than the values obtained with the standard manometric assay used throughout this study. Substrate inhibition was not observed at concentration levels well in excess of $16.7 \mathrm{~mm}$. This concentration of L-malate was found to be saturating and was used routinely for the standard assays.

The specific activity for the standard L-malate PMS reductase assay was $11.0 \mu$ atoms of oxygen per min per mg of protein at $37 \mathrm{C}$, at a PMS concentration of $2.2 \mathrm{~mm}$. The theoretical $V_{\max }$ for this assay, calculated at infinite PMS concentration, was 15.1 and the $K_{\mathrm{m}}$ value for PMS was $0.0028 \mathrm{M}$.

The kinetic parameters for the L-malate $\mathrm{K}_{3}$ reductase assay, calculated at infinite vitamin $\mathrm{K}_{3}$ concentration, were a $V_{\max }$ of 45.5 and $K_{\mathrm{m}}$ for $\mathrm{K}_{3}$

TABLE 2. Effect of FAD, FMN, and riboflavine on $L$-malate oxidation by the Azotobacter $R_{3}$ fraction

\begin{tabular}{|c|c|c|c|}
\hline \multirow{2}{*}{ Assay system } & \multicolumn{3}{|c|}{ Specific activity ${ }^{a}$} \\
\hline & $\mathrm{O}_{2}$ & PMS & $\mathbf{K}_{\mathbf{3}}$ \\
\hline $\begin{array}{l}\text { Control } \\
\text { Control }+\mathrm{CN}\left(2 \times 10^{-3} \mathrm{M}\right)\end{array}$ & \begin{tabular}{|l|}
0.36 \\
0
\end{tabular} & 1.52 & 3.00 \\
\hline$\underset{\mathbf{M})}{\text { Control }}+$ riboflavine $\left(10^{-4}\right.$ & 0.36 & 1.36 & 2.98 \\
\hline $\begin{array}{l}\text { Control + FMN }\left(10^{-4} \mathrm{M}\right) \\
\text { Control + FAD }\left(10^{-4} \mathrm{M}\right)\end{array}$ & \begin{tabular}{|l|}
0.33 \\
0.63
\end{tabular} & $\begin{array}{l}1.66 \\
3.61\end{array}$ & $\begin{array}{l}2.39 \\
8.75\end{array}$ \\
\hline $\begin{array}{l}\text { Control }+ \text { FAD + CN }(2 \\
\left.\times 10^{-3} \mathrm{M}\right)\end{array}$ & & & \\
\hline $\begin{array}{l}\text { Control + FAD }+\mathrm{Ca}^{++} \\
\left(2 \times 10^{-3} \mathrm{M}\right)\end{array}$ & 1.01 & 8.91 & 19.21 \\
\hline $\begin{array}{l}\text { Control + FAD + } \mathrm{Ca}^{++} \\
+\mathrm{CN}\left(2 \times 10^{-3} \mathrm{M}\right)\end{array}$ & 0 & & \\
\hline
\end{tabular}

a See Table 1.
TABLE 3. Kinetic parameters established for $L$ malate oxidation by the Azotobacter $R_{3}$ electron transport fraction

\begin{tabular}{l|l|l|c|c}
\hline \multirow{2}{*}{$\begin{array}{c}\text { Variable assay } \\
\text { component }\end{array}$} & $\begin{array}{c}\text { Kinetic } \\
\text { parameter }\end{array}$ & \multicolumn{3}{|c}{ L-Malate oxidation assaya } \\
\cline { 3 - 5 } & & Oxidase & $\begin{array}{c}\text { PMS } \\
\text { reductase }\end{array}$ & $\begin{array}{c}\mathrm{K}_{2} \\
\text { reductase }\end{array}$ \\
\hline L-Malate & $V_{\max }{ }^{b}$ & 3.4 & $11.5^{c}$ & $26.3^{d}$ \\
& $K_{\operatorname{m}}$ & 0.0041 & 0.0032 & 0.0071 \\
PMS & $V_{\max }$ & & $15.1^{e}$ & \\
$\mathrm{~K}_{3}$ & $K_{\mathrm{m}}$ & & 0.0028 & \\
& $V_{\max }$ & & & $45.5^{e, f}$ \\
& $K_{\mathrm{m}}$ & & & 0.0018 \\
\hline
\end{tabular}

a Assays were performed with $4 \times 10^{-6} \mathrm{M}$ FAD and $2 \times 10^{-3} \mathrm{M} \mathrm{CaCl}_{2}$.

${ }^{b}$ Expressed in micrograms of oxygen per minute per milligram of protein at $37 \mathrm{C}$.

${ }^{c}$ The final concentration of PMS in the assay was $2.2 \mathrm{~mm}$.

${ }^{d}$ The final concentration of $K_{3}$ in the assay was $1.2 \mathrm{~mm}$.

- The final concentration of L-malate was $16.7 \mathrm{~mm}$.

$f$ Concentrations greater than $1.2 \mathrm{mM}$ of $\mathrm{K}_{3}$ were inhibitory for the $K_{3}$ reductase assay.

of $0.0018 \mathrm{M}$. Concentrations of vitamin $\mathrm{K}_{3}$ in excess of $1.2 \mathrm{~mm}$ were inhibitory, and, for this reason, activities close to the theoretical $V_{\max }$ value could never be obtained for the L-malate$\mathbf{K}_{3}$ reductase assay. Instead, specific activities of approximately $50 \%$ of the $V_{\max }$ value, or 26.3 $\mu$ atoms of oxygen per min per $\mathrm{mg}$ of protein, were obtained routinely with the standard assay in which a $1.2 \mathrm{~mm}$ concentration of vitamin $\mathrm{K}_{3}$ and $16.7 \mathrm{~mm}$ L-malate were used.

Spectrophotometric assays. L-Malate oxidation in the Azotobacter $\mathbf{R}_{3}$ fraction was examined also with various other artificial electron acceptors. The highest turnover rates were obtained with the PMS-mediated L-malate cytochrome $c$ or DCIP reductases. For these two assays, specific activities of 2.05 and $1.65 \mu$ moles, respectively, of L-malate (or $2 e^{-}$) oxidized per min per $\mathrm{mg}$ of protein at $25 \mathrm{C}$ were obtained. The specific activity for the L-malate $\mathrm{K}_{3} \mathrm{Fe}(\mathrm{CN})_{6}$ reductase was 0.36 and the activities for L-malate oxidation with DCIP and NBT as the sole electron acceptors were 0.09 and 0.08 , respectively. Cytochrome $c$ served as the poorest acceptor and gave a specific activity value of $0.04 \mu$ mole of L-malate oxidized per min per $\mathrm{mg}$ of protein at $25 \mathrm{C}$.

Distribution of activities for L-malate oxidation. A fractionation scheme, which shows the distribution of the various activities for L-malate oxidation in cell-free extracts of $A$. vinelandii, was devised. The fractionation, shown in Table 4, was carried out by differential centrifugation of son- 
ically disrupted resting cells of $A$. vinelandii. The supernatant and residue fractions were designated " $S$ " and " $R$," respectively. $S_{1}$ was the original sonic-treated extract obtained from the disrupted Azotobacter cells after centrifugation at $4,300 \times g$ for $10 \mathrm{~min}$. The $S_{1}$ fraction was centrifuged further at $37,000 \times g$ for $20 \mathrm{~min}$, and the residue $\mathbf{R}_{2}$ fraction from this centrifugation was obtained. The resultant supernatant $S_{2}$ fraction was then centrifuged for $2 \mathrm{hr}$ at $144,000 \times g$ and the $R_{3}$ and $\mathrm{S}_{3}$ fractions were obtained. A more complete description of this differential centrifugation procedure was published elsewhere $(27,29)$.

In essence, all the activity associated with Lmalate oxidation, regardless of the acceptor used, concentrated in the particulate $R_{3}$ fraction (Table 4). Specific activities for all the L-malate oxidation assays were always highest with this fraction, and the predominant portion of the activity units concentrated here.

Difference spectra of the Azotobacter $\mathbf{R}_{\mathbf{3}}$ fraction. An analysis of the difference spectra of the Azotobacter $\mathbf{R}_{\mathbf{3}}$ fraction revealed that the membranebound cytochrome and flavoprotein components were reduced readily by L-malate. Partial steadystate reduction was achieved by the addition of L-malate (" $\mathrm{m}$ ") and the subsequent reduction that was attained by the addition of sodium dithionite ("d"; Fig. 1). The addition of L-malate completely reduced cytochrome $a_{2}(629 \mathrm{~nm})$ and cytochrome $a_{1}(600 \mathrm{~nm})$ but partially reduced cytochromes $b_{1}(561$ and $531 \mathrm{~nm})$ and $c_{4}+c_{5}(553$ and $523 \mathrm{~nm}$ ). Only a small portion of the flavoprotein (and possibly nonheme iron) was reduced by L-malate, as shown by the trough in the 457 $\mathrm{nm}$ region. No appreciable steady-state reduction of the electron carriers was detected when cyanide

TABLE 4. Distribution of activity units for $L$-malate oxidation in fractions obtained by differential centrifugation from sonically disrupted resting cells of Azotobacter vinelandii

\begin{tabular}{|c|c|c|c|c|c|c|c|}
\hline \multirow{2}{*}{ Fraction } & \multirow{2}{*}{$\begin{array}{c}\text { Pro- } \\
\text { tein } \\
\text { re- } \\
\text { covery }\end{array}$} & \multicolumn{6}{|c|}{$\begin{array}{l}\text { Specific activity }{ }^{a} \text { and recovery } \\
\text { of activity units }\end{array}$} \\
\hline & & $\mathrm{O}_{2}$ & $\mathbf{T U}^{b}$ & PMS & $\mathbf{T} \mathbf{U}^{b}$ & $\mathrm{~K}_{\mathbf{3}}$ & $\mathrm{TU}^{\mathrm{b}}$ \\
\hline & $\%$ & & $\%$ & & $\%$ & & $\%$ \\
\hline $\mathbf{S}_{1}$ & 100 & 0.14 & 100 & 2.08 & 100 & 14.99 & 100 \\
\hline $\mathbf{S}_{2}$ & 62 & 0.12 & 54 & 2.32 & 67 & $|10.03|$ & 42 \\
\hline $\mathbf{R}_{2}$ & 26 & 0.13 & 24 & 1.01 & 13 & 3.67 & 24 \\
\hline $\mathbf{S}_{2}$ & 100 & 0.12 & 100 & 2.32 & 100 & $|10.03|$ & 100 \\
\hline $\mathbf{S}_{3}$ & 57 & 0.001 & 3 & 0.89 & 23 & 1.92 & 11 \\
\hline $\mathbf{R}_{\mathbf{3}}$ & 48 & 0.24 & 96 & 4.53 & 98 & 17.30 & 83 \\
\hline
\end{tabular}

a See Table 1.

b Total units (TU) were calculated by multiplying total protein concentration by specific activity. $\left(10^{-8} \mathrm{M}\right)$ was added to the test cuvette in the absence of L-malate or when the test cuvette was made anaerobic by evacuation. When, however, cyanide was added during steady-state reduction by L-malate, all of the cytochrome components were reduced to the dithionite level, although no effect was noted on the extent of bleaching in the flavoprotein region. It can be concluded by these steady-state reduction studies that the cytochrome and flavoprotein components of the Azotobacter $\mathbf{R}_{3}$ electron transport fraction were reduced substantially, although not maximally, by L-malate.

Sensitivity to electron transport inhibitors. The L-malate oxidase activity of the Azotobacter $\mathbf{R}_{\mathbf{3}}$ fraction was examined for its sensitivity to electron transport inhibitors. These titrations (Fig. 2) were made in the presence of both FAD and $\mathrm{CaCl}_{2}$, and the values shown in brackets represent the molar concentration at which the $50 \%$ inhibition values were estimated by interpolation. As shown, chlorpromazine and $p$-CMB were the most effective inhibitors. The next most effective inhibitors of the L-malate oxidase activity were HQNO (19.1 $\mu \mathrm{g}$ per mg of protein), $\mathrm{KCN}$, and antimycin $\mathrm{A}$ (34.3 $\mu \mathrm{g}$ per $\mathrm{mg}$ of protein). Other electron transport inhibitors were tested, but these were found to be less effective. Amytal at $2 \times 10^{-8} \mathrm{M}$ caused only a $9 \%$ inhibition, whereas TFTB at a concentration of $4.0 \times 10^{-4} \mathrm{M}(239$ $\mu \mathrm{g}$ per $\mathrm{mg}$ of protein) inhibited the L-malate oxidase by $33 \%$. Rotenone, at $2 \times 10^{-4}$ and $1 \times 10^{-3} \mathrm{M}$, inhibited the L-malate oxidase activity by 50 and $65 \%$, respectively.

Sensitivity to chelating agents. The L-malate oxidase was most sensitive to EDTA; $5 \times 10^{-6} \mathrm{M}$ caused $40 \%$ inhibition. Other chelators, namely, $o$-phenanthroline and 8-hydroxyquinoline, at a concentration level of $10^{-4} \mathrm{M}$, inhibited the L-malate oxidase activity by 20 and $8 \%$, respec-

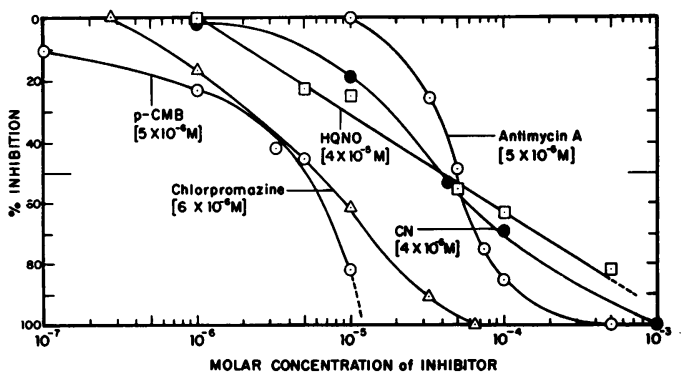

FIG. 2. Effect of increasing concentrations of electron transport inhibitors on the L-malate oxidase activity of Azotobacter $R_{3}$ fraction. The inhibitor titrations were performed at $30 \mathrm{C}$ in the presence of both $\mathrm{Ca}^{++}$ion $\left(2 \times 10^{-8} \mathrm{M}\right)$ and FAD $\left(4 \times 10^{-5} \mathrm{M}\right)$. The values in brackets indicate the molar concentration of inhibitor at which a $50 \%$ inhibition was estimated by interpolation. 
tively. At $3.3 \times 10^{-4} \mathrm{M}, \alpha, \alpha$-dipyridyl caused only a $6 \%$ inhibition.

\section{DISCUSSION}

The L-malate oxidoreductase of $\mathrm{A}$. vinelandlii is a particulate enzyme apparently bound to the electron transport system. Studies from numerous laboratories revealed that the enzyme fraction possessing L-malate oxidoreductase activity also contained high concentrations of flavoprotein, coenzyme $\mathrm{Q}_{8}$, cytochromes $b_{1}, c_{4}+c_{5}, o, a_{1}$, and $a_{2}$, and nonheme iron. The L-malate oxidoreductase of $A$. vinelandii strain $\mathrm{O}$ utilized vitamin $\mathrm{K}_{3}$, PMS, molecular $\mathrm{O}_{2}, \mathrm{~K}_{3} \mathrm{Fe}(\mathrm{CN})_{6}$, DCIP, NBT, and cytochrome $c$ as electron acceptors. The L-malate vitamin $\mathrm{K}_{3}$ reductase from the A. vinelandii $\mathrm{R}_{3}$ fraction was unlike that found in Acetobacter xylinum as it was not sensitive to cyanide.

The Azotobacter L-malate oxidase was sensitive to such inhibitors as $p$-CMB, chlorpromazine, $\mathrm{HQNO}, \mathrm{KCN}$, and antimycin A (Fig. 1). This is in contrast to the L-malate oxidoreductase of $M$. lysodeikticus, which was insensitive to both antimycin A and cyanide (21).

As with the L-malate oxidoreductase of Mycobacterium phlei, M. avium, Acetobacter xylinum, and $P$. ovalis, the L-malate oxidoreductase in $\mathrm{Azo}$ tobacter vinelandii strain $\mathrm{O}$ was specifically stimulated by FAD. This is in contrast to the findings reported for $A$. vinelandii strain 8660 NCIB in which the L-malate oxidoreductase in cell-free extracts was not stimulated by externally added FAD (25). Jones and Redfearn $(25,26)$ examined this particulate enzyme in strain 8660 and showed that it was neither NAD- nor NADP-dependent and that it did not require a supernatant fraction for the rapid oxidation of L-malate. They reported that FAD did not stimulate the particulate Lmalate oxidoreductase of $A$. vinelandii strain 8660 when enzyme assays were performed by the use of an oxygen electrode. A similar lack of FAD stimulation was also observed when the L-malate oxidoreductase of the $\mathrm{R}_{3}$ fraction of $A$. vinelandii strain $\mathrm{O}$ was assayed by the polarographic technique. However, FAD stimulation could be demonstrated if the enzyme from strain $O$ was dialyzed extensively before assay with the oxygen electrode. This treatment resulted in a marked loss of enzymatic activity, a small part of which was restorable by adding FAD. Both Azotobacter strains contained the same cytochromes, flavine and ubiquinone $Q_{8}$, but no menaquinone $\left(\mathrm{K}_{2}\right)$ could be detected in $A$. vinelandii strain 8660 , although it was found in strain $O$ (25).

The L-malate oxidoreductase of the Azotobacter $\mathbf{R}_{3}$ fraction was stimulated nonspecifically by externally added divalent cations. Plaut and Lardy (42) reported that certain divalent cations increased the rate of enzymatic decarboxylation of oxalacetate to pyruvate and $\mathrm{CO}_{2}$ in cell-free extracts of $A$. vinelandii. Furthermore, higher concentrations of these same metal ions increased even the nonenzymatic decarboxylation rate of this highly unstable acid. The metal ion stimulation observed with the L-malate oxidoreductase of the Azotobacter $\mathbf{R}_{3}$ might be attributed to the decarboxylation of oxalacetate, which is the primary end product of $L$-malate oxidation. The increased rate of removal of oxalacetate by decarboxylation could drive the initial reaction, the oxidation of L-malate to oxalacetate. This type of metal ion stimulation was not reported for the L-malate oxidoreductase in other microorganisms.

Unlike the flavine found in the enzyme preparation of Mycobacterium avium and Acetobacter xylinum, the flavine moiety of the Azotobacter Lmalate oxidoreductase in the $\mathbf{R}_{\mathbf{3}}$ fraction could not be dissociated by dialysis or by ammonium sulfate-acid fractionation (37). The Azotobacter L-malate oxidoreductase in the $\mathbf{R}_{3}$ fraction remained active during the ammonium sulfate-acid treatment, and the FAD stimulation of the treated enzyme was almost identical to that noted for the untreated $\mathbf{R}_{3}$ preparation. In contrast to the enzyme from Micrococcus lysodiekticus (13) and Mycobacterium phlei $(3-5,33)$, the L-malate oxidoreductase from the Azotobacter $\mathbf{R}_{3}$ fraction from strain $\mathrm{O}$ did not depend upon any factors in the supernatant liquid for activity.

The clarified supernatant liquid or $\mathrm{S}_{3}$ fraction of $A$. vinelandii contained slight but significant amounts of L-malate, vitamin $\mathrm{K}_{3}$, and PMS reductase activities (Table 4). This suggests that the L-malate oxidoreductase of the $\mathbf{R}_{3}$ fraction has been partially dissociated from the electron transport chain by the sonic-treatment procedure used in preparing the enzyme. Such soluble L-malate vitamin $K$ reductases have also been described in $M$. phlei $(3,5,33)$, in $A$. xylinum $(7,10,31)$, in $M$. avium (47), and in $P$. ovalis $(17,41)$. As in these other microorganisms, the soluble $\left(\mathrm{S}_{3}\right)$ fraction of Azotobacter vinelandii contained no significant L-malate oxidase activity. Residual amounts of the $b$ - and $c$-type cytochromes are present in the $S_{3}$ fraction, although cytochromes $a_{1}, a_{2}$, and $o$ appear to be absent. These latter cytochromes are believed to be responsible for terminal oxidase function.

Specific activities for L-malate oxidation by the Azotobacter $\mathrm{R}_{3}$ fraction were unusually high when compared to the activities reported for other microorganisms. This could be a reflection of the high metabolic activity that is commonly found in Azotobacter species. 


\section{ACKNO WLEDGMENTS}

This investigation was supported by Public Health Service grant GM-12279 from the National Institute of General Medical Sciences.

A. J. Bednarz was a National Defense Education Act predoctoral fellow, Department of Microbiology, University of Texas, Austin.

\section{LITERATURE GITED}

1. Alexander, M., and P. W. Wilson. 1955. Enzyme localization in Azotobacter vinelandii. Proc. Nat. Acad. Sci. U.S.A. 41:843-848.

2. Alexander, M., and P. W. Wilson. 1956. Intracellular distribution of tricarboxylic acid cycle enzymes in Azotobacter vinelandii. J. Bacteriol. 71:252-253.

3. Asano, A., and A. F. Brodie. 1963. Oxidative phosphorylation in fractionated bacterial systems. XII. The properties of malate-vitamin $\mathbf{K}$ reductase. Biochem. Biophys. Res. Commun. 13:423-427.

4. Asano, A., and A. F. Brodie. 1964. Oxidative phosphorylation in fractionated bacterial systems. XIV. Respiratory chains of Mycobacterium phlei. J. Biol. Chem. 239:4280-4291.

5. Asano, A., T. Kaneshiro, and A. F. Brodie. 1965. Malatevitamin $K$ reductase, a phospholipid-requiring enzyme. J. Biol. Chem. 240:895-905.

6. Benziman, M., and A. Abeliovitz. 1964. Metabolism of dicarboxylic acids in Acetobacter xylinum. J. Bacteriol. 87:270-277.

7. Benziman, M., and Y. Galanter. 1964. Flavine adenine dinucleotide-linked malic dehydrogenase of Acetobacter xylinum. J. Bacteriol. 88:1010-1018.

8. Benziman, M., and H. Goldhamer. 1968. The role of ubiquinone in the respiratory chain of Acetobacter xylinum. Biochem. J. 108:311-316.

9. Benziman, M., and L. Levy. 1966. Phosphorylation coupled to malate oxidation in Acetobacter xylinum. Biochem. Biophys. Res. Commun. 24:214-217.

10. Benziman, M., and L. Perez. 1965. The participation of vitamin $\mathbf{K}$ in malate oxidation by Acetobacter xylinum. Biochem. Biophys. Res. Commun. 19:127-131.

11. Brodie, A. F., and J. Adelson. 1965. Respiratory chains and sites of coupled phosphorylation. Science 149:265-269.

12. Bruemmer, J. H., P. W. Wilson, J. L. Glenn, and F. L. Crane. 1957. Electron transporting particle from Azotobacter vinelandii. J. Bacteriol. 73:113-116.

13. Cohn, D. V. 1956. The oxidation of malic acid by Micrococcus lysodiekticus. J. Biol. Chem. 221:413-423.

14. Cohn, D. V. 1958. The enzymatic formation of oxalacetic acid by nonpyridine nucleotide malic dehydrogenase of Micrococcus lysodiekticus. J. Biol. Chem. 233:299-304.

15. Cota-Robles, E. H., A. G. Marr, and E. H. Wilson. 1958. Submicroscopic particles in extracts of Azotobacter agilis. J. Bacteriol. 75:243-252.

16. Francis, M. J. O., D. E. Hughes, H. L. Kornberg, and P. J. R. Phizackerley. 1963. The oxidation of L-malate by Pseudomonas sp. Biochem. J. 89:430-438.

17. Francis, M. J. O., and P. J. R. Phizackerley. 1965. Kephalin requirement for L-malate oxidase of Pseudomonas ovalis Chester. Biochem. J. 95:25-26.

18. Gel'man, N. S., M. A. Lukoyanova, and A. I. Oparin. 1960. The cytochrome system in the cytoplasmic membranes of Micrococcus lysodiekticus. Biokhimiya (Transl.) 25:482-486.

19. Gel'man, N. S., I. G. Zhukova, M. A. Lukoyanova, and A. I Oparin. 1959. Succinic oxidase and malic oxidase in the structural elements of Micrococcus lysodiekticus. Biokhimiya (Transl.) 24:481-487.

20. Gel'man, N. S., I. G. Zhukova, and A. I. Oparin. 1960 Oxidation of L-malic acid and of reduced diphosphopyridine nucleotide in the cytoplasmic membrane of Micrococcus lysodiekticus. Dokl. Akad. Nauk. S.S.S.R. 133:12091212.
21. Gel'man, N. S., I. G. Zhukova, and A. I. Oparin. 1963. The preparation of dehydrogenases of L-malic acid and the rereduced form of diphosphopyridine nucleotide from the cytoplasmic membrane of Micrococcus lysodiekticus. Biokhimiya (Transl.) 28:95-99.

22. Gel'man, N. S., I. G. Zhukova, and N. I. Zaitseva. 1962. Flavin nucleotides of the cytoplasmic membranes of $\mathrm{Mi}$. crococcus lysodiekticus. Dokl. Akad. Nauk. S.S.S.R. 145: 206-208.

23. Gornall, A. G., C. J. Bardawill, and M. M. David. 1949. Determination of serum proteins by means of the biuret reaction. J. Biol. Chem. 177:751-766.

24. Hatef, Y., A. G. Haavik, and D. E. Griffiths. 1961. Reconstitution of the electron transport system. I. Preparation and properties of the interacting enzyme complexes. Biochem. Biophys. Res. Commun. 4:441-446.

25. Jones, C. W., and E. R. Redfearn. 1966. Electron transport in Azotobacter vinelandii. Biochim. Biophys. Acta 113: 467-481.

26. Jones, C. W., and E. R. Redfearn. 1967. The cytochrome system of Azotobacter vinelandii. Biochim. Biophys. Acta 143:340-353.

27. Jurtshuk, P., P. R. Aston, and L. Old. 1967. Enzymatic oxidation of tetramethyl-p-phenylenediamine and $p$-phenylenediamine by the electron transport particulate fraction of Azotobacter vinelandii. J. Bacteriol. 93:1069-1078.

28. Jurtshuk, P., and L. Harper. 1968. Oxidation of $D(-)$ lactate by the electron transport fraction of Azotobacter vinelandii. J. Bacteriol. 96:678-686.

29. Jurtshuk, P., S. Manning, and C. R. Barrera. 1968. Isolation and purification of the $\mathrm{D}(-) B$-hydroxybutyric dehydrogenase of Azotobacter vinelandii Can. J. Microbiol. 14:775783.

30. Jurtshuk, P., and L. Old. 1968. Cytochrome $c$ oxidation by the electron transport fraction of Azotobacter vinelandii. J. Bacteriol. 95:1790-1797.

31. Karniely, Y., and M. Benziman. 1966. Solubilization of FADlinked malate dehydrogenase of Acetobacter xylinum. Israel J. Chem. 4:75-76.

32. Kimura, T., and J. Tobari. 1963. Participation of flavin adenine dinucleotide in the activity of malate dehydrogenase from Mycobacterium avium. Biochim. Biophys. Acta 73:399-405.

33. Kurup, C. K. R., and A. F. Brodie. 1967. Nonheme iron: a functional component of malate-vitamin $\mathbf{K}$ reductase. Biochem. Biophys. Res. Commun. 28:862-868.

34. Kurup, C. K. R., and A. F. Brodie. 1967. Oxidative phosphorylation in fractionated bacterial systems. XXIX. The involvement of nonheme iron in the respiratory pathways of Mycobacterium phlei. J. Biol. Chem. 242:5830-5837.

35. Lester, R. L., and A. Smith. 1961. Studies on the electron transport system. XXVII. Mode of reduction of tetrazolium salts by beef heart mitochondria; role of coenzyme $Q$ and other lipids. Biochim. Biophys. Acta 47:475-496.

36. Lukoyanova, M. A., N. S. Gel'man, and A. I. Oparin. 1963. The electron transport chain in the cytoplasmic membranes of Micrococcus lysodiekticus. Biokhimiya (Transl.) 28:801807.

37. Mahler, H. R. 1954. Studies on the fatty acid oxidizing systems of animal tissues. IV. The prosthetic group of butyryl coenzyme A dehydrogenase. J. Biol. Chem. 206:13-26.

38. Margoliash, E. 1954. The use of ion exchangers in the preparation and purification of cytochrome c. Biochem. J. 56: 529-535.

39. Oparin, A. I., and N. S. Gel'man. 1965. Action of a lipase and a phospholipase on the activity of dehydrogenases in an enzyme preparation of Micrococcus lysodiekticus membranes. Dokl. Akad. Nauk. S.S.S.R. 161:237-240.

40. Pangborn, J., A. G. Marr, and S. A. Robrish. 1962. Localization of respiratory enzymes in intracytoplasmic membranes of Azotobacter agilis. J. Bacteriol. 84:669-678. 
41. Phizackerley, P. J. R., and M. J. O. Francis. 1966. Cofactor requirements of the L-malate dehydrogenase of Pseudomonas ovalis Chester. Biochem. J. 101:524-535.

42. Plaut, G. W. E., and H. A. Lardy. 1949. The oxalacetate decarboxylase of Azotobacter vinelandii. J. Biol. Chem. 180:13-27.

43. Repaske, R., and P. W. Wilson. 1953. Oxidation of intermediates of the tricarboxylic acid cycle by extracts of Azotobacter agile. Proc. Nat. Acad. Sci. U.S.A. 39:225-232.

44. Saini, A. S. 1967. Some technical improvements in the paper chromatography of keto acid 2,4-dinitrophenylhydrazones. Chromatography 26:539-541.

45. Shriner, R. L., R. C. Fuson, and D. Y. Cutin. 1965. The systematic identification of organic compounds. John Wiley \& Sons, Inc., New York, p. 126

46. Tissieres, A., H. G. Hovenkamp, and E. C. Slater. 1957. The respiratory enzyme system of Azotobacter vinelandii. Biochim. Biophys. Acta 25:336-347.
47. Tobari, J. 1964. Requirement of flavin adenine dinucleotide and phospholipid for the activity of malate dehydrogenase from Mycobacterium avium. Biochem. Biophys. Res. Commun. 15:50-54.

48. Tobari, J., and T. Kimura. 1966. Isolation of vitamin $\mathbf{K}_{2}$ derivative acting as electron acceptor for malate dehydrogenase. J. Biochem. (Tokyo) 60:470-472.

49. Watanabee, T., and A. F. Brodie. 1966. Enzymatic formation of a phospholipid derivative of vitamin $K_{1}$. Proc. Nat. Acad. Sci. U.S.A. 56:940-945.

50. Yamamura, Y., M. Kusunose, S. Nagai, and E. Kusunose. 1954. Studies on the tricarboxylic acid cycle in tubercule bacillis. J. Biochem. (Tokyo) 41:513-528.

51. Ziegler, D. M., and K. A. Doeg. 1962. Studies on the electron transport system. XLIII. The isolation of a succinic-coenzyme $Q$ reductase from beef heart mitochondria. Arch. Biochem. Biophys. 97:41-50. 